\title{
The Risk Factors of Pancreatic Cancer Patients in Dr. Cipto Mangunkusumo National Hospital, Jakarta During 2014-2019
}

\author{
Kaka Renaldi*, Teddy Septianto**, Dadang Makmun* \\ *Division of Gastroenterology, Department of Internal Medicine \\ Faculty of Medicine, Universitas Indonesia/Dr. Cipto Mangunkusumo General National Hospital, Jakarta \\ **Department of Internal Medicine, Faculty of Medicine, Universitas Indonesia/ \\ Dr. Cipto Mangunkusumo General National Hospital, Jakarta
}

\begin{abstract}
Corresponding author:
Kaka Renaldi. Division of Gastroenterology, Department of Internal Medicine, Dr. Cipto Mangunkusumo General National Hospital. Jl. Diponegoro No. 71 Jakarta Indonesia. Phone: +62-21-3153957; Facsimile: +62-21-3142454.E-mail: kakarenaldi@gmail.com
\end{abstract}

\begin{abstract}
Background: Pancreatic cancer is a very rare cancer with age-adjusted rates ranging from about 5 to 10 new cases per 100,000 persons per year. It has one of the worst prognoses of any type of cancer, with a 5-year survival rate of only $4.6 \%$. Several risk factors have been identified, including older age, smoking, familial history of pancreatic cancer, obesity, chronic pancreatitis, diabetes mellitus, and alcohol consumption.

Method: This was a descriptive study describing the risk factors of patients who were diagnosed with pancreatic cancer in the period between 1 January 2014 - 1 January 2019 at the Cipto Mangunkusumo National Referral Hospital (RSCM) Jakarta. Data were obtained from the medical records and endoscopic retrograde cholangiopancreatography (ERCP) database from the Gastrointestinal Endoscopy Center, Cipto Mangunkusumo Hospital.

Results: From January 2014 to January 2019 there were 123 patients with newly diagnosed pancreatic cancer in Cipto Mangunkusumo Hospital. The mean age was 52 years old. The incidence of pancreatic cancer is more common in men (53\%) than women (47\%). The most common risk factor identified is smoking which was found in $29 \%$ of patients, followed by obesity at $27.9 \%$ and a history of diabetes mellitus at 19.5\%. Risk factors with a fairly low prevalence include alcohol consumption at $9.7 \%$ and chronic pancreatitis at $2.4 \%$. No family history of pancreatic cancer is identified in any subject.

Conclusion: Smoking, obesity, and diabetes mellitus are common risk factors in pancreatic cancer patients. In contrast, chronic pancreatitis, alcohol consumption, and family history of pancreatic cancer are less commonly identified in patients.
\end{abstract}

Keywords: pancreatic cancer, risk factors, Indonesia

\footnotetext{
ABSTRAK

Background: Kanker pankreas adalah kanker yang sangat langka dengan insidensi sebanyak 5-10 kasus per 100.000 orang per tahun. Prognosisnya merupakan salah satu yang terburuk di antara seluruh jenis kanker, di mana tingkat kesintasan 5 tahun hanya sebesar 4,6\%. Beberapa faktor risiko kanker pankreas telah diidentifikasi, antara lain usia tua, merokok, adanya riwayat keluarga kanker pankreas, obesitas, pankreatitis kronik, diabetes mellitus, dan konsumsi alkohol.
} 
Metode: Penelitian ini merupakan studi deskriptifyang bertujuan untuk mengidentifikasi faktor risiko pada pasien kanker pankreas yang berobat di Rumah Sakit Cipto Mangunkusumo (RSCM), Jakarta pada periode di antara 1 Januari 2014 - 1 Januari 2019. Data diperoleh dari rekam medis dan dari data endoscopic retrograde cholangiopancreatography (ERCP) dari Pusat Endoskopi Gastroenterologi RSCM.

Hasil: Dari periode Januari 2014 hingga Januari 2019, terdapat 123 pasien dengan diagnosis baru kanker pankreas di RSCM. Rerata usia pasien adalah 52 tahun. Insidensi kankrer pankreas lebih tinggi pada laki-laki (53\%) dibandingkan perempuan (47\%). Faktor risiko yang paling sering diidentifikasi adalah merokok yang dijumpai pada $29 \%$ pasien, diikuti oleh obesitas yang dijumpai pada 27,9\% pasien, dan riwayat diabetes mellitus yang dijumpai pada 19,5\% pasien. Faktor risiko dengan prevalensi yang rendah meliputi konsumsi alkohol yang dijumpai pada 9,7\% pasien dan pankreatitis kronik yang dijumpai pada 2,4\% pasien. Tidak ada subjek yang memiliki riwayat keluarga kanker pankreas.

Simpulan: Perilaku merokok, obesitas, dan diabetes mellitus merupakan faktor risiko yang sering dijumpai pada pasien kanker pankreas. Sebaliknya, pankreatitis kronik, konsumsi alkohol, dan riwayat keluarga kanker pankreas jarang ditemui pada pasien.

Kata kunci: kanker pankreas, faktor risiko, Indonesia

\section{INTRODUCTION}

Pancreatic cancer is a very rare cancer with the ageadjusted rates in most countries ranging from about 5 to 10 new cases per 100,000 persons per year. ${ }^{1}$ Despite its relative scarcity, this tumor has attracted increasing interest because the mortality rate is nearly $100 \%{ }^{1}$ Most patients who are diagnosed with this tumor die within a year. ${ }^{1}$ Only very few tumors are as aggressive as pancreatic cancer and unlike many other cancers, the discovery of a small tumor does not always lead to improved survival. ${ }^{1}$

Pancreatic cancer arises from the cells of the pancreas. ${ }^{1}$ Most pancreatic cancers are from the exocrine component of the pancreas, which is the part of the pancreas that produces digestive enzymes. ${ }^{1}$ The exact causes of pancreatic cancer are unknown, although several risk factors have been identified, including age, smoking, mutations in certain genes, familial history of pancreatic cancer, obesity, chronic pancreatitis, diabetes mellitus, and alcohol consumption. ${ }^{1}$ Pancreatic cancer is a lethal condition with poor outcomes and an increasing incidence. ${ }^{2}$ Pancreatic cancer has one of the worst prognoses of any type of cancer, with a 5-year survival rate of only $4.6 \%$ and a median survival rate of fewer than 6 months. ${ }^{2}$ Although pancreatic cancer accounted for less than $2 \%$ of new cancer incidence, it is the fourth leading cause of cancer mortality and accounts for $6 \%$ of all cancer deaths. ${ }^{2}$ The best chance for curing the disease is by early detection and surgery, which has a 5 -year survival rate of approximately $21 \%$ when combined with chemotherapy. ${ }^{2}$

Globocan estimates revealed that there were 458,918 diagnoses and 432,242 deaths from pancreatic cancer globally in $2018 .{ }^{3}$ The incidence rates vary significantly between countries. The highest age-standardized incidence is seen in Europe and North America, and the lowest is in Africa and South-Central Asia. ${ }^{3}$ There is a general trend of higher incidence rates in developed countries compared to developing countries. This is supported by Wong et al, who demonstrated that there were higher incidences of pancreatic cancer in both males and females in countries with higher human development index. ${ }^{4}$ This study aims to investigate the prevalence of risk factors in patients with pancreatic cancer, especially in Cipto Mangunkusumo National Referral Hospital Jakarta, Indonesia. From the results of this study, we can use the information to modify some of the risk factors that can hopefully prevent the development of pancreatic cancer. This study can also provide some information about the incidence of pancreatic cancer which had previously been found to be rarer in South East Asia than in the other region.

\section{METHOD}

This was a descriptive study that describes the risk factors of patients who were diagnosed with pancreatic cancer in the period between 1 January $2014-1$ January 2019 at the Cipto Mangunkusumo National Referral Hospital Jakarta. Data were obtained from the patients' medical records who were diagnosed with pancreatic cancer by histopathology and from the Endoscopic Retrograde Cholangiopancreatography (ERCP) database stored at the Gastrointestinal Endoscopy Center, Cipto Mangunkusumo Hospital. The clinical data extracted for this study were age, sex, smoking and alcohol consumption history, family history of pancreatic cancer, obesity, and 
previous history of chronic pancreatitis. Patients with incomplete data were excluded from the study. Data were analyzed using SPSS statistics 20.0 to obtain the clinical descriptive data of the pancreatic cancer patients in Cipto Mangunkusumo Hospital.

\section{RESULTS}

From January 2014 to January 2019 there were 123 patients with newly diagnosed pancreatic cancer in Cipto Mangunkusumo Hospital The mean age was 52 , with the age range from 25 to 79 years old. The incidence of pancreatic cancer was more common in men $(53 \%)$ than women $(47 \%)$. The pancreatic cancer was more commonly diagnosed with EUS-FNA and subsequently confirmed with histopathological examination. Most patients presented with obstructive jaundice and cancer pain.

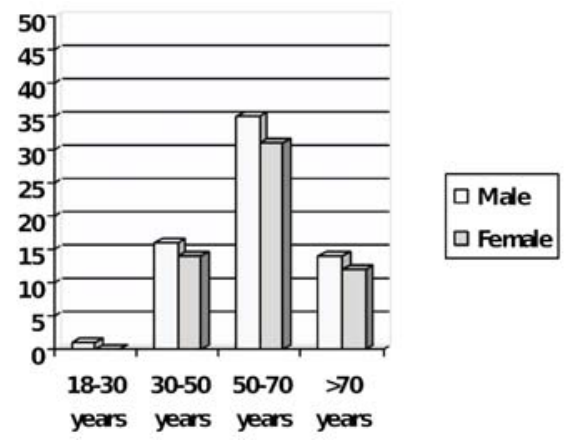

Figure 1. Age groups of the pancreatic cancer patients in Cipto Mangunkusumo National Referral Hospital, Jakarta, Indonesia

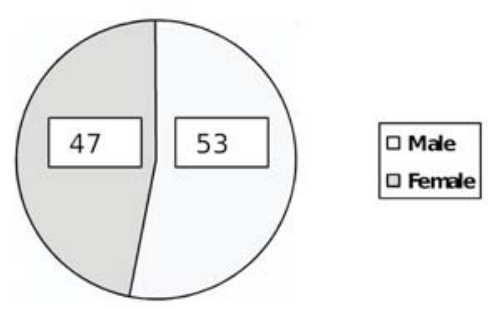

Figure 2. Gender of the pancreatic cancer patients in Cipto Mangunkusumo Hospital, Jakarta, Indonesia

Information about the risk factors of patients with pancreatic cancer was obtained from medical records. Specifically, we tried to look for the presence of risk factors for pancreatic cancer which had been well established in the literature. We hoped to assess whether these risk factors also play a role in the pancreatic cancer patient population in Indonesia, especially in the Cipto Mangunkusomo Hospital. Data from Globocan 2018 showed that pancreatic cancer ranked as the $17^{\text {th }}$ highest incidence of cancer in Indonesia based on cancer types, with an incidence of 4,940 cases in 2018 and a mortality rate of 4,812 people. $^{3}$ The results of this study indicated that several risk factors have been found in some subjects with pancreatic cancer. The results showed that of the 123 patients with pancreatic cancer, the prevalence of smoking was found in $29 \%$ of patients, the prevalence of obesity was $27.9 \%$, and the prevalence of diabetes mellitus was $19.5 \%$. Risk factors with fairly low prevalence include alcohol consumption at $9.7 \%$ and chronic pancreatitis at $2.4 \%$. Interestingly, no family history of pancreatic cancer was found in the study subjects.

Table 1. The Prevalence of the risk factors in pancreatic cancer patients at Cipto Mangunkusumo National Referral Hospital, Jakarta, Indonesia

\begin{tabular}{ll}
\hline \multicolumn{1}{c}{ Risk factors } & \multicolumn{1}{c}{$\begin{array}{c}\text { Prevalence }(\mathbf{n}=\mathbf{n} \text { (23) } \\
\text { n }\end{array}$} \\
\hline Diabetes Mellitus & $24(19.5)$ \\
Family history of pancreatic cancer & $0(0)$ \\
Smoking & $36(29)$ \\
Alcohol consumption & $12(9.7)$ \\
Chronic pancreatitis & $3(2.4)$ \\
Obesity & $34(27.6)$ \\
\hline
\end{tabular}

\section{DISCUSSION}

Pancreatic cancer is a malignant disease that is primarily found in elderly patients. ${ }^{5}$ It is extremely rare for patients to be diagnosed before the age of 30 . Around $90 \%$ of newly diagnosed patients are over 55 years old, with the majority in their $7^{\text {th }}$ and $8^{\text {th }}$ decade of life. ${ }^{5}$ The age at which the incidence peaks varied between countries. In India, the peak incidence occurs in patients in their sixth decade of life, whereas in the United States this occurs in the seventh decade of life. ${ }^{5}$ Our study showed similar results, which showed that the average age of pancreatic cancer diagnosis was at 52 years old and most of the patient was in the 50-70 years old age group.

Based on the Globocan survey in 2018, it was mentioned that the prevalence of pancreatic cancer occurs slightly higher in males compared to females (age-standardized rate of 5.5 in males compared to 4.0 in females). ${ }^{3}$ This disparity appeared to be greater in the higher development index countries. Despite the sex difference, a systematic review of 15 studies concluded that reproductive factors were not associated with the risk of developing pancreatic cancer. ${ }^{3}$ These findings point towards differing exposures in the environment or genetic factors as alternative explanations for the male predominance. ${ }^{3}$ From the results of our study, we also found that the prevalence of males was slightly higher at around $53 \%$. The higher prevalence in male in this study may be caused by the higher prevalence of 
smoking in male than female (male smoker $=56.25 \%$; female smoker $=0 \%$ ).

Based on the results of various studies, it was concluded that the risk of developing pancreatic cancer increased if two or more first-degree relatives had previously been diagnosed with the disease. This risk factor accounts for about $5-10 \%$ of new cases. ${ }^{6}$ Patients with familial risk factors have a nine times higher risk of developing pancreatic cancer than those without a family history, and this risk increases about thirty-two times greater if three or more first-degree relatives had a history of pancreatic cancer. ${ }^{6}$ A meta-analysis of nine studies had also reported that in individuals with a family history of only one first degree relative that had been diagnosed with pancreatic cancer, they still had an $80 \%$ increased risk of developing pancreatic ductal adenocarcinoma $(\mathrm{RR}=1.8 ; 95 \% \mathrm{CI}: 1.48-2.12) .{ }^{6}$ However, the results of our study did not find any patients with a familial history of pancreatic cancer. This could mean that familial history played a lesser role in the development of pancreatic cancer in the Indonesian population. On the other hand, it might also reflect underreporting, underdiagnosis, or lack of documentation by the clinicians.

Diabetes is a well-established risk factor for pancreatic cancer. Pancreatic cancer occurs with a higher frequency among individuals with diabetes. ${ }^{2}$ A comprehensive meta-analysis of 36 studies also demonstrated a similar magnitude of increased risk of pancreatic cancer in patients with type-2 diabetes $\left(\mathrm{OR}=1.82\right.$; 95\%CI: 1.66-1.89). ${ }^{2}$ However, it must be noted that although diabetes is a risk factor, pancreatic cancer can also presents with a new onset of diabetes. This has led to an interest in $\mathrm{HbAlc}$ as a potential biomarker of early detection in pancreatic cancer. ${ }^{2}$ The risk of pancreatic cancer was $50 \%$ higher if diabetes was diagnosed within the preceding 5 years. ${ }^{2}$ Although earlier studies have focused on type 2 diabetics, a recent meta-analysis by Stevens and coworkers found that type 1 diabetes also increased the risk of pancreatic cancer by 2 -fold $(\mathrm{RR}=2.0 ; 95 \% \mathrm{CI}, 1.37-3.01){ }^{2}$ Chari and associates estimated that $1 \%$ of diabetic subjects over 50 years of age will be diagnosed with pancreatic cancer within 3 years after meeting the diagnostic criteria for diabetes. ${ }^{7}$ However, the high prevalence of diabetes in the general population excludes hyperglycemia as a practical screening tool for pancreatic cancer. ${ }^{7}$ Hyperglycemia may become more relevant as a screening test if it becomes possible to differentiate pancreatic cancer-induced diabetes from other causes of hyperglycemia using better clinical characteristics or the use of serologic markers. ${ }^{7}$ From the results of our study, the prevalence of diabetes mellitus was $19.5 \%$ in patients with pancreatic cancer. The diagnosis of diabetes mellitus in this study was based on the medical records and the laboratory values of patients. These results were consistent with previous research where diabetes mellitus had been shown to cause pancreatic cancer. There may be multiple mechanisms by which diabetes mellitus can cause increased risk of pancreatic cancer. In the early stage of type II diabetes mellitus, hyperinsulinemia may occur as a compensatory response for the insulin resistance. The hyperinsulinemia can cause the proxicrine effect, in which the high insulin hormone secreted by pancreatic $\beta$-cells binds to the insulin and IGF-1 receptors of the acinar and ductal cells located near the $\beta$-cells. The binding of insulin to those receptors exerts anti-apoptotic and proliferative effects to the cells, which may lead to carcinogenesis. ${ }^{8}$ Besides, patients who have type II diabetes mellitus often have concomitant obesity, which is also associated with increased risk of pancreatic cancer. ${ }^{8}$

Smoking is considered to be the most important modifiable risk factor in pancreatic cancer, with multiple individual and combined studies demonstrating a strong positive association. ${ }^{2}$ The Panc4 study combined data from 12 case-control studies from which there were 6507 cancer cases and 12890 controls. ${ }^{9}$ The results demonstrated a significantly increased risk of pancreatic cancer in ever-smokers and it was doseresponsive. ${ }^{9}$ A meta-analysis of 82 published studies found that there was a $74 \%$ increased risk of pancreatic cancer in current $(\mathrm{OR}=1.74 ; 95 \% \mathrm{CI}$ : 1.61-1.87) and a $20 \%$ increased risk in former smokers $(\mathrm{OR}=1.20$; 95\%CI: 1.11-1.29) compared to never smokers. ${ }^{9}$ The study also found that following smoking cessation, the risk remains for at least 10 years while others have shown it may take up to 20 years following smoking cessation for the risk to return to baseline. ${ }^{9}$ The Pancreatic Cancer Cohort Consortium has reported similar findings, and also found the risk increased with both the duration of smoking $(>50$ years $\mathrm{OR}=$ 2.13; 95\% CI: 1.25-3.62) and the number of cigarettes smoked ( $>30$ cigarettes/d, OR $=1.75$; 95\% CI: 1.27 2.42). ${ }^{9}$ A novel area for future research which remains unanswered currently is about the effect of e-cigarettes with regard to the pancreas health. E-cigarettes deliver heated nicotine, but contain fewer chemicals than tobacco smoking, and have generally been promoted as safer (but not necessarily safe) alternatives to traditional cigarettes. ${ }^{10}$ New studies are required to 
determine the risk and benefit of e-cigarettes which can have unknown carcinogenic potential, or as a helpful smoking cessation tool contributing to pancreatic cancer prevention. ${ }^{10}$ Similar result was found in our study, which showed that the prevalence of smokers in patients with pancreatic cancer was $29 \%$. This might show a positive association between smoking and pancreatic cancer, although further observational studies need to be conducted.

Many studies tried to link the relationship between alcohol consumption and also the incidence of pancreatic cancer. ${ }^{2}$ This link is still not certain, but heavy alcohol use can lead to conditions such as chronic pancreatitis, which is known to increase the risk of pancreatic cancer. Multiple studies have investigated the impact of alcohol consumption on the development of pancreatic cancer but the results have been mixed. ${ }^{2}$ A pooled analysis of 14 cohort studies with 2187 cases of pancreatic cancer found an increased risk when patients consumed $>30 \mathrm{~g}$ of alcohol per day $(\mathrm{RR}=1.22$; 95\% CI: $1.03-1.45) .{ }^{11}$ The most recent meta-analysis found that low and moderate alcohol consumption was not associated with increased pancreatic cancer risk. However, those with high alcohol consumption had a $15 \%$ increased risk of pancreatic cancer ( $\mathrm{RR}=1.15 ; 95 \% \mathrm{CI}: 1.06-1.25 ; \mathrm{p}$ $=0.001)$. This increased risk was the largest in heavy male drinkers, particularly of spirits. ${ }^{11}$ The results of our study showed that only about $9.7 \%$ of pancreatic cancer patients consumed alcohol regularly before this. This may be due to the culture in Indonesia where alcohol is not consumed regularly.

Chronic pancreatitis is a progressive inflammatory condition of the pancreas leading to fibrosis associated with the loss of acinar and islet cells. ${ }^{2}$ Chronic pancreatitis can be caused by an inherited gene mutation. People with this inherited (familial) form of pancreatitis have a high lifetime risk of pancreatic cancer. ${ }^{2}$ Significant variety exists in the reported incidence of this disease, ranging from 2-14/100.000 of the United States population. Approximately $5 \%$ of these patients will develop pancreatic cancer during their lifetime. ${ }^{2}$ Pooled results from seven studies investigating chronic pancreatitis patients found a 13fold higher risk of developing pancreatic cancer (RR: $=13.3 ; 95 \% \mathrm{CI}$ : $6.1-28.9)$ compared with the general population or controls. ${ }^{2}$ The relatively low incidence and the potential to increase cancer risk implied that chronic pancreatitis patients could be a potential target group for pancreas cancer screening if an effective test can be found and long latency period accounted for. ${ }^{2}$ The results of this study showed that only $2.4 \%$ of pancreatic cancer patients had a history of chronic pancreatitis. As discussed previously, this might be caused by low alcohol consumption in Indonesia, as alcohol consumption is one of the main etiology for the development of chronic pancreatitis.

The worldwide prevalence of obesity is increasing with an estimate of 1.97 billion adults and 338 million children and adolescents categorized as overweight or obese in $2016 .^{2}$ Excessive body weights appear to increase the risk of pancreatic cancer. ${ }^{2}$ The World Cancer Research Fund in the pancreatic cancer report from 2012 identified 23 studies that assessed for an association between a raised body mass index (BMI) and pancreatic cancer. Nineteen of these individual studies reported an increased risk of pancreatic cancer in obese patients. The meta-analysis performed on these studies showed that there was a 10\% increased risk of pancreatic cancer for every increase of $5 \mathrm{BMI}$ units $(\mathrm{RR}=1.10 ; 95 \% \mathrm{CI}: 1.07-1.14)$ with no difference in the outcomes between males and females. ${ }^{2}$ The Health Professionals Follow-up Study and the Nurses Health Study found that men and women with a body mass index (BMI) of at least $30 \mathrm{~kg} / \mathrm{m}^{2}$ had a $72 \%$ increased risk of pancreatic cancer when compared to those with a BMI of less than $23 \mathrm{~kg} / \mathrm{m}^{2}(\mathrm{RR}=1.72$; 95\% CI: 1.19 2.48). ${ }^{2}$ Physical activity appeared to reduce the risk of pancreatic cancer by $55 \%(\mathrm{RR}=$ 0.45; 95\% CI: 0.29-0.70). In the Cancer Prevention Study II, the risk of pancreatic cancer was $41 \%$ higher in subjects with a BMI between $30.0 \mathrm{~kg} / \mathrm{m}^{2}$ and 34.9 $\mathrm{kg} / \mathrm{m}^{2}(\mathrm{RR}=1.41 ; 95 \% \mathrm{CI}: 1.19-1.66)$ when compared to those with a normal BMI $\left(<25 \mathrm{~kg} / \mathrm{m}^{2}\right){ }^{2}$ Given the strength of the evidence linking obesity to pancreatic cancer, it is likely that the rising incidence of obesity is a major risk factor for the increasing incidence of pancreatic cancer in the developed world. ${ }^{2}$ The results of our study showed that the prevalence of obesity in patients with pancreatic cancer was $27.6 \%$. This might indicate a positive association between obesity and the incidence of pancreatic cancer. There have been large public health campaigns that promote healthier lifestyles especially advocating the decrease in alcohol consumption and cigarette smoking. Similar campaigns need to focus on educating the public on the health risks associated with obesity.

Since this is a descriptive study, we can not determine whether the risk factors are truly associated with increased risk of pancreatic cancer. However, the risk factors investigated in these studies have been established as major risk factors for pancreatic 
cancer. Regarding family history, there may be undiagnosed pancreatic cancer in the patient's family, since CT scan and advanced imaging modalities are not widely available in all parts of the country. Underdocumentation by clinician may also explain the lack of family history of pancreatic cancer. We also did not specify the type of pancreatic cancer in this study, although the most common is pancreatic ductal adenocarcinoma. However, this is one of the first study documenting the prevalence of risk factors in Indonesian pancreatic cancer patients. The results from this study can be explored for future studies.

\section{CONCLUSION}

This study showed that several risk factors that are thought to increase the risk of pancreatic cancer were prevalent in the patient population. There was a high proportion of patients who were smokers, obese, and had diabetes mellitus. On the other hand, the prevalence of patients with chronic pancreatitis, alcohol consumption, and family history of pancreatic cancer was small.

\section{REFERENCES}

1. Lowenfels A, Maisonneuve P. Risk factors for pancreatic cancer. Journal of Cellular Biochemistry 2005;95:649-56.

2. McGuigan A, Kelly P, Turkington R, Jones C, Coleman H, McCain R. Pancreatic cancer: A review of clinical diagnosis, epidemiology, treatment and outcomes. World J Gastroenterol 2018;24:4846-61.

3. International Agency for Research on Cancer, World Health Organization. Global Cancer Observatory 2018; [serial online] [cited 2020 Feb 2]. Available from: URL: http://gco.iarc.fr/.

4. Wong MCS, Jiang JY, Liang M, Fang Y, Yeung MS, Sung JJY. Global temporal patterns of pancreatic cancer and association with socioeconomic development. Sci Rep 2017;7:3165.

5. McMenamin ÚC, McCain S, Kunzmann AT. Do smoking and alcohol behaviours influence GI cancer survival? Best Pract Res Clin Gastroenterol 2017;31:569-77.

6. Hruban RH, Canto MI, Goggins M, Schulick R, Klein AP. Update on familial pancreatic cancer. Adv Surg 2010;44:293-311.

7. Decker GA, Batheja MJ, Collins JM, Silva AC, Mekeel KL, Moss AA, et al. Risk factors for pancreatic adenocarcinoma and prospects for screening. Gastroenterol Hepatol (NY) 2010;6:246-54.

8. Andersen DK, Korc M, Petersen GM, Eibl G, Li D, Rickels MR, et al. Diabetes, pancreatogenic diabetes, and pancreatic cancer. Diabetes 2017;66:1103-10.

9. Bosetti C, Lucenteforte E, Silverman DT, Petersen G, Bracci PM, Ji BT, et al. Cigarette smoking and pancreatic cancer: an analysis from the International Pancreatic Cancer CaseControl Consortium (Panc4). Ann Oncol 2012;23:1880-8.

10. Iodice S, Gandini S, Maisonneuve P, Lowenfels AB. Tobacco and the risk of pancreatic cancer: a review and meta-analysis. Langenbecks Arch Surg 2008;393:535-45.
11. Genkinger JM, Spiegelman D, Anderson KE, Bergkvist L, Bernstein L, van den Brandt PA, et al. Alcohol intake and pancreatic cancer risk: a pooled analysis of fourteen cohort studies. Cancer Epidemiol Biomarkers Prev 2009;18:765-76. 